Original Article

\title{
Physical chemical and citotoxic evaluation of highly diluted solutions of Euphorbia tirucalli L. prepared through the fifty milesimal homeopathic method
}

\author{
Sheila Garcia ${ }^{1}$, Rafael Cardoso Harduim², Fortune Homsani², Carlos Renato \\ Zacharias $^{3}$, Ricardo Machado Kuster ${ }^{4}$, Carla Holandino ${ }^{2}$
}

1Laboratório de Controle de Qualidade, Departamento de Medicamentos, Faculdade de Farmácia, UFRJ. Rio de Janeiro, Brazil.

2Laboratório Multidisciplinar de Ciências Farmacêuticas, Departamento de Medicamentos, Faculdade de Farmácia, UFRJ. Rio de Janeiro, Brazil.

${ }^{3}$ Departamento de Física e Química, UNESP, Guaratinguetá, São Paulo, Brazil. ${ }^{4}$ Núcleo de Pesquisa em Produtos Naturais, UFRJ. Rio de Janeiro, Brazil.

\begin{abstract}
Background: although Hahnemann described the fifty-milesimal (LM) method in the $6^{\text {th }}$ edition of the Organon of the Medical Art, very little research has been carried out on the physical chemical properties of these homeopathic preparations. Furthermore, there is still no evidence allowing for the correlation between the alleged physical chemical properties and the biological effects of high dilutions. Aims: to evaluate physical chemical characteristics of LM preparations including electrical conductivity, $\mathrm{pH}$ and refraction index, and their effect on biological experimental models. Materials and methods: preparations tested for physical chemical analysis were dilutions $1 \mathrm{~lm}$ to $10 \mathrm{~lm}$ of Euphorbia tirucalli L. prepared from the latex and the juice of the plant. To rule the seasonal characteristics of this plant, 2 different populations were used, one collected in June 2007 and the other in May 2008. Furthermore, the cytotoxic effect of Euphorbia tirucalli $5 \mathrm{~lm}$ was tested on human breast cancer cells (MCF7) through MTT assay. Conclusions: Some differences among the two collections were observed. However, any clear correlation could be observed between physical chemical properties and biological activity.
\end{abstract}

Keywords: High dilutions, LM method, electrical conductivity, $\mathrm{pH}$, refraction index, cytotoxicity, Euphorbia tirucalli

\section{Introduction}

Recently published literature describes some physical chemical properties of highly diluted aqueous solutions (HDs) [1-9], electrical conductivity seems a fitting indicator of structural changes in water induced by HDs [2,10-11]. However, the possible interactions between a highly diluted substance and water are still not well understood [5-6,12].

In this context, a particular method of preparation of homeopathic solutions known as fifty-milesimal (LM) has been little researched as to physical chemical properties, although it was described by Samuel Hahnemann, the founder of homeopathy, in the $6^{\text {th }}$ edition of his major opus, the Organon of the Healing Art, finished in 1842 and published in 1925 [13-14]. 
Former investigations with HD of Euphorbia tirucalli L. showed that it can be used as a model for study physical chemical changes [10-11]. Therefore, it was used as motivation to prepare LM dilutions in order to establish potential alterations of physical chemical variables.

On the other hand, there is no data in the literature linking alleged physical chemical properties of HDs and their biological effects. For this reason, in this study we also sought to establish biological effects of HDs of Euphorbia tirucalli L. and attempt to correlate them with eventual changes in the physical chemical variables.

In this regard, the latex of Euphorbia tirucalli L. is used in folk medicine to treat chronic degenerative diseases [15-17], although the mechanisms involved in this activity are not yet known. According to the literature, the latex may have dual behavior, activating or inhibiting tumoral events [18-20].

In a previous study [21], we found interesting results on the effect of HDs of Euphorbia tirucalli L. on the glycolytic metabolism of cancer and normal cells (Melan A and MCF-7 cell lines), supporting the hypothesis that they interfere the metabolism of cell lines. Moreover, using mice as experimental subjects, it could be observed that the ones that received Euphorbia tirucalli in dilution $30 \mathrm{cH}$ exhibited significant increase in food consumption $(p<0.05)$ without any significant difference in weight gain, indicating an influence of this HD on animal metabolism [22].

The aims of this study were to verify whether the electrical conductivity, $\mathrm{pH}$ and refraction index of HDs of Euphorbia tirucalli L. prepared according to the LM method present significant changes in different degrees of dilution and to establish whether electrical conductivity correlates with biological parameters, in this case the cytotoxicity of Euphorbia tirucalli on in human breast cancer cells (MCF7 line).

\section{Materials and Methods}

\section{Preparation of HDs}

The experiments were carried out with the juice of the whole plant and the latex of Euphorbia tirucalli $\mathrm{L}$. gathered from the garden of Núcleo de Pesquisa de Produtos Naturais of Universidade Federal do Rio de Janeiro, Brazil. The plants were gathered at the beginning of June 2007 and in mid-May 2008, in order to avoid seasonal variations.

The juice and the latex were grinded separately in lactose up to $3 \mathrm{cH}$ as described by Hahnemann and the Brazilian Homeopathic Pharmacopeia [13,23]. Then, it was taken 1 grain $(63 \mathrm{mg})$ from the 3cH preparation and it was dissolved, with gentle shaking, in 400 drops of distilled water and 100 drops of alcohol 96\% (v/v), totalizing 500 drops. This is the standard starting potency in the LM method whose ratio is 1 grain (63mg) to 500 drops. One drop $(0.025 \mathrm{ml})$ from the starting potency was mixed with 100 drops $(2.5 \mathrm{ml})$ of alcohol $96 \%$ (v/v). This solution was agitated by 100 handmade succussions. This is the first degree in the $1 \mathrm{~m}$ method (1 $\mathrm{lm}$ ). 500 microglobules (weighing $315 \mathrm{mg}$ ) were impregnated with the solution $1 \mathrm{~lm}$, homogenized and left to dry naturally, each one of these being $1 \mathrm{~lm}$. One microglobule was placed in an amber-hued vial (capacity $4.5 \mathrm{ml}$ ) and 1 drop of distilled water was added to dissolve it. Then 100 drops of alcohol $96 \%$ (v/v) were added in the vial and hand succussed 100 times to obtain the second degree. One drop of the latter was used to impregnate 500 microglobules, which were homogenized and left to dry naturally $(2 \mathrm{~lm})$. The process was thus repeated to obtain dilutions $3 \mathrm{~lm}$ to $10 \mathrm{~lm}$.

As controls, we used distilled water (DW) and diluted-agitated lactose (LDLM), following the same procedure. 
Electrical conductivity, $\mathrm{pH}$ and refraction index were evaluated in the HDs of Euphorbia tirucalli $1 \mathrm{~lm}$ to 10 $\mathrm{lm}$ prepared from both the latex and the juice of the full plant. Electrical conductivity and the $\mathrm{pH}$ measurements were made with Mettler-Toledo MPC 227 at $25^{\circ} \mathrm{C}$.

A Zeiss Refractometer was used to measure the refraction index. For these assays 3 microglobules were placed in 3 different amber glass vials (1 microglobule in each vial) and solubilized with $30 \mathrm{ml}$ of distilled water.

\section{Cytotoxicity assay}

Euphorbis tirucalli $5 \mathrm{~lm}$ was prepared from the plants gathered in May 2008, and its cytotoxicity was evaluated by MTT assay in MCF- 7 cells. For that purpose, confluent MCF7 cells (5 X 104 cells) were seeded in 96 well plates with 5\% and 10\% HDs and their respective controls and kept in incubation for 24 hours [22]. At the end of treatments, $20 \mu \mathrm{l}$ of $5 \mathrm{mg} / \mathrm{ml}$ solution of tetrazolium reagent (3,4,5-dimethiazol-2,5-diphenyltetrazolium bromide, Sigma) were added to each well. Culture plates were incubated for further 3 hours at $37^{\circ} \mathrm{C}$ in the absence of light. Supernatant was removed and formazan crystals were dissolved with $200 \mu \mathrm{l}$ of dimethylsulfoxide. Absorbance was measured in each well in dual wave-length, according to Mosmann [24].

\section{Statistical analysis}

Student's test was used to evaluate the significance of results. In all analyses, confidence interval was $95 \%$ and $\mathrm{p}$ values less than 0.05 were considered significant.

\section{Results and Discussion}

\section{Physical chemical parameters of HDs prepared from plants gathered in June 2007}

The results obtained in the measurement of $\mathrm{pH}$ and refraction index of all LM dilutions of Euphorbia tirucalli exhibited no statistical difference ( $p>0.05$ ) (data not shown). On the other hand, the measurement of electrical conductivity in the latex and whole plant juice of the plants collected in June 2007 (Figure 1) presented statistically significant differences, as described in Table 1.

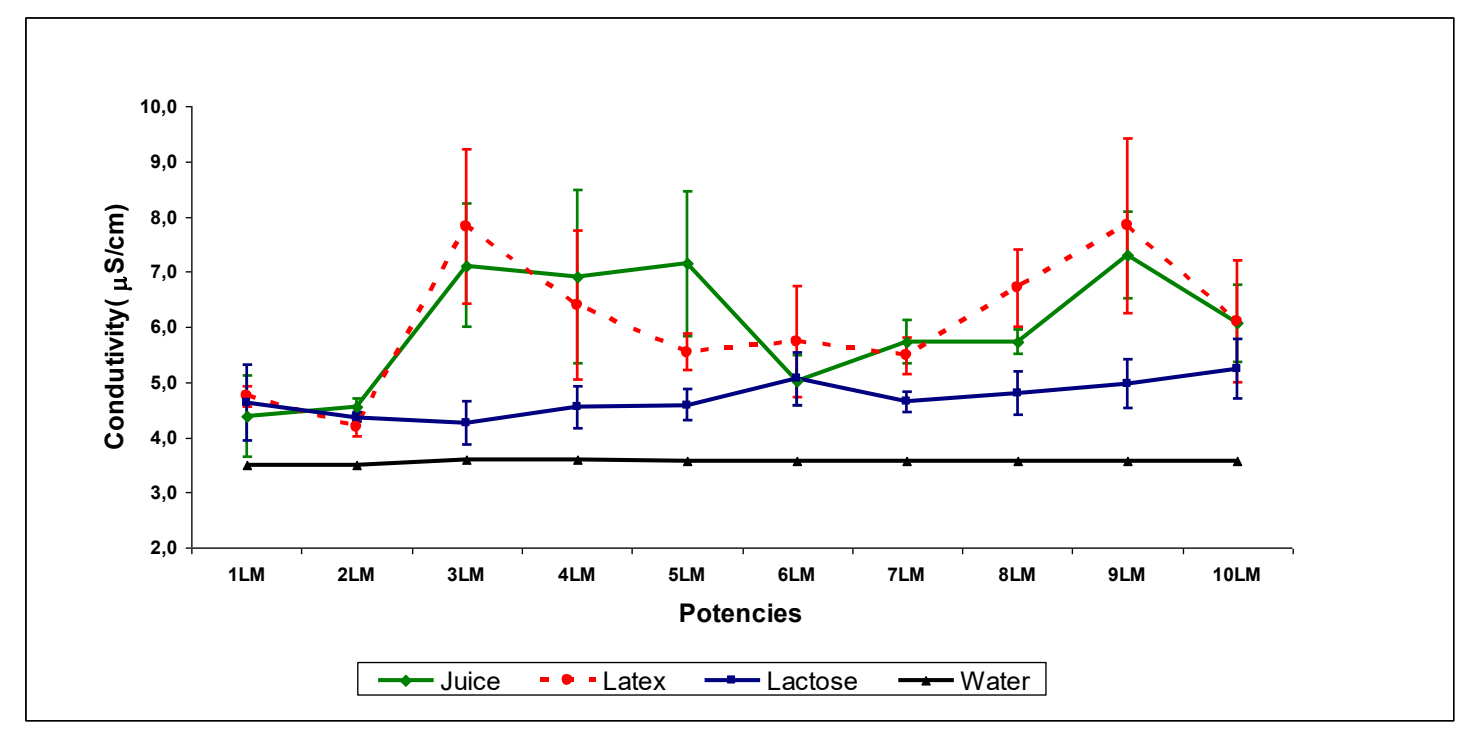

Figure 1: Results of conductivity measurement in latex and juice of E. tirucalli collected in June 2007 and respective controls. Three measurements were made independently $(n=3)$.

Statistical treatment was made using the values obtained from the latex and the juice, considering "p value" with $95 \%$ confidence interval. The dilutions exhibiting more significant differences were analysed (Table 1). 
Table 1: Statistical treatment of the dilutions chosen from the latex and the juice of E. tirucalli collected in June 2007, considering "p value" with 95\% confidence interval.

\begin{tabular}{|c|c|c|}
\hline Dilutions & Latex (p-value) & Juice (p-value) \\
\hline $1 \mathrm{~lm}$ vs $3 \mathrm{~lm}$ & 0.054 & 0.078 \\
\hline $1 \mathrm{~lm}$ vs $5 \mathrm{~lm}$ & 0.101 & $0.016^{*}$ \\
\hline $1 \mathrm{~lm}$ vs $8 \mathrm{~lm}$ & $0.046^{*}$ & 0.117 \\
\hline $1 \mathrm{~lm}$ vs $9 \mathrm{~lm}$ & 0.092 & $0.032^{*}$ \\
\hline $3 \mathrm{~lm}$ vs $5 \mathrm{~lm}$ & 0.106 & 0.977 \\
\hline $5 \mathrm{~lm}$ vs $9 \mathrm{~lm}$ & 0.129 & 0.837 \\
\hline
\end{tabular}

*Statistically significant difference

Results of the statistical analysis of the changes in the measurements of electrical conductivity obtained from the latex were not significant enough as to exclude the possibility of chance (they presented high standard deviations - Figure 2), excluding * $1 \mathrm{~lm}$ vs. $8 \mathrm{~lm}$, which exhibited statistically significant change (Table 1). For juice samples, t-test showed statistically significant change between ${ }^{*} 1 \mathrm{~lm}$ vs $5 \mathrm{~lm}$ and ${ }^{*} 1 \mathrm{~lm}$ vs $9 \mathrm{~lm}$ (Table 1 ).

The results for the control HD lactose (LDLM) prepared exactly in the same way as the latex and the juice are shown in Table 2 . There is statistically significant difference between lactose and latex, and lactose and juice with $3 \mathrm{~lm}, 5 \mathrm{~lm}, 7 \mathrm{~lm}, 8 \mathrm{~lm}$ and $9 \mathrm{~lm}$.

Table 2: Statistical treatment of conductivity measurements between lactose and latex, and lactose and juice of plants gathered in June 2007, considering "p value" with 95\% confidence interval.

\begin{tabular}{|c|c|c|}
\hline Dilutions & $\begin{array}{c}\text { Lactose vs Latex } \\
\text { (p-value) }\end{array}$ & $\begin{array}{c}\text { Lactose vs Juice } \\
\text { (p-value) }\end{array}$ \\
\hline $3 \mathrm{~lm}$ & $0.014^{*}$ & $0.014^{*}$ \\
\hline $4 \mathrm{~lm}$ & 0.084 & 0.064 \\
\hline $5 \mathrm{~lm}$ & $0.021^{*}$ & $0.030^{*}$ \\
\hline $6 \mathrm{~lm}$ & 0.360 & 0.947 \\
\hline $7 \mathrm{~lm}$ & $0.018^{*}$ & $0.013^{*}$ \\
\hline $8 \mathrm{~lm}$ & $0.015^{*}$ & $0.023^{*}$ \\
\hline $\mathbf{9} \mathrm{lm}$ & $0.039^{*}$ & $0.011^{*}$ \\
\hline $\mathbf{1 0} \mathrm{lm}$ & 0.290 & 0.182 \\
\hline
\end{tabular}

*Statistically significant difference

As $\mathrm{pH}$ values did not change significantly over all LM potencies, we could not correlate them with the values for electric conductivity.

Physical chemical parameters of HDs prepared from plants gathered in May 2008 
The refraction index and $\mathrm{pH}$ values all HDs tested did not differ significantly (data not shown), as it was also the case of the plants collected in June 2007. Electrical conductivity showed a similar profile of values as the one obtained with the plants gathered in June 2007 (Figure 2 and Table 3).

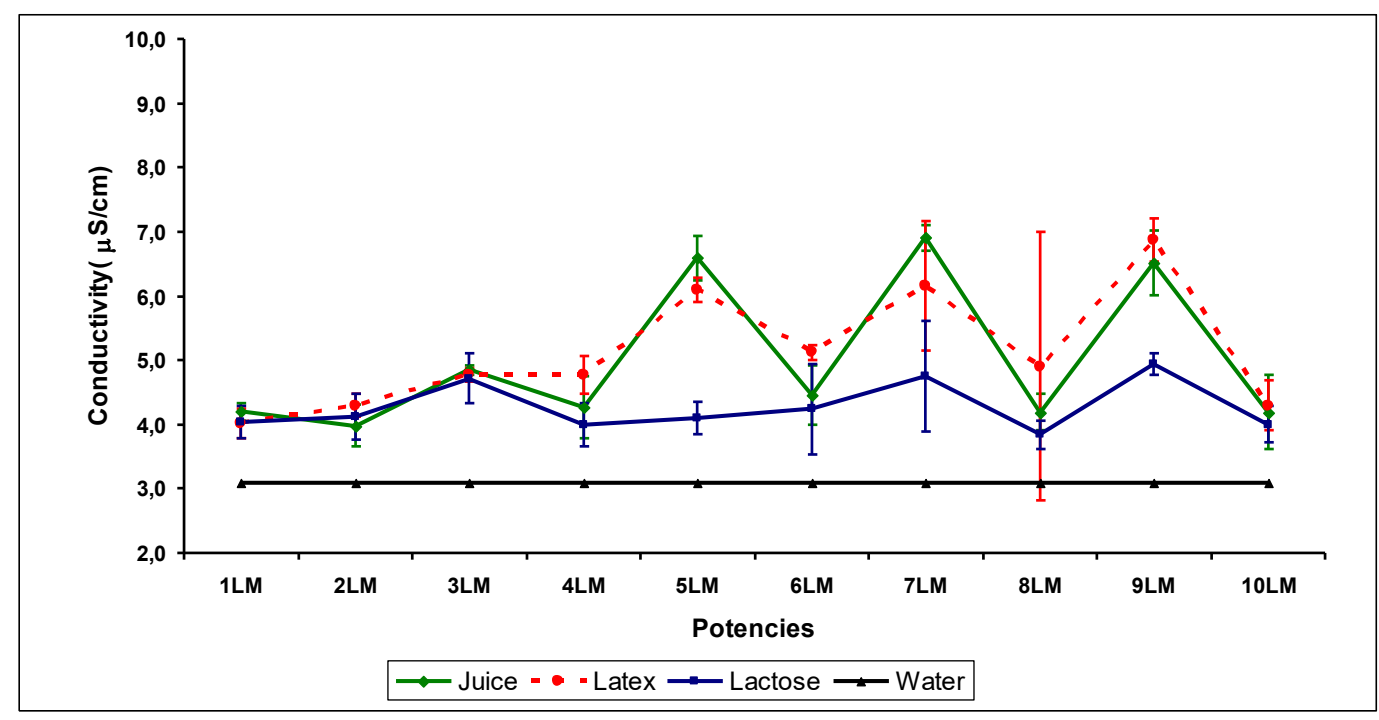

FIGURE 2: Results of conductivity measurement from latex and juice of the plants gathered in May 2008 and respective controls. Three measurements were made independently $(n=3)$.

The differences observed in the profiles obtained from both sets of plants should be attributed to the phytochemical composition of this Euphorbiaceae. Varricchio quantified the latex of E. tirucalli with high performance liquid chromatography coupled with UV absorption spectrometry (CLAE/UV) for 1 year [25], and the results indicate that the phytochemical composition of this latex has seasonal variations. Moreover, this study confirmed that the maximum synthesis of phorbol esthers occurred during the morning period in the month of May [25]. Additionally, the comparative study made between plants gathered in May and in June showed different cytotoxic properties induced by dilution 30cH on tumor cells [26]. Seasonal aspects might be involved in the phytochemical properties of E. tirucalli, and consequently affect the properties its HDs.

TABLE 3: Statistical treatment of the dilutions chosen from the latex and juice of E. tirucalli gathered in May 2008, considering "p value" with 95\% confidence interval.

\begin{tabular}{|c|c|c|}
\hline Dilutions & Latex (p-value) & Juice (p-value) \\
\hline $1 \mathrm{~lm}$ vs $3 \mathrm{~lm}$ & 0.056 & 0.028 \\
\hline $1 \mathrm{~lm}$ vs $5 \mathrm{~lm}$ & $0.006^{*}$ & $0.006^{*}$ \\
\hline $1 \mathrm{~lm}$ vs $8 \mathrm{~lm}$ & 0.569 & 0.117 \\
\hline $1 \mathrm{~lm}$ vs $9 \mathrm{~lm}$ & $0.004^{*}$ & $0.013^{*}$ \\
\hline $3 \mathrm{~lm}$ vs $5 \mathrm{~lm}$ & $0.013^{*}$ & $0.018^{*}$ \\
\hline $5 \mathrm{~lm}$ vs $9 \mathrm{~lm}$ & 0.119 & 0.526 \\
\hline
\end{tabular}

*Statistically significant difference 
T-test showed statistically significant change between * $1 \mathrm{~lm}$ vs $5 \mathrm{~lm}$, * $1 \mathrm{~lm}$ vs $9 \mathrm{~lm}$ and *3 $\mathrm{lm}$ vs $5 \mathrm{~lm}$. The comparisons of latex and juice with the control HD lactose (LDLM) is in table 4. There is statistically significant difference between lactose and latex, and lactose and juice with $5 \mathrm{~lm}, 7 \mathrm{~lm}, 8 \mathrm{~lm}$ and $9 \mathrm{~lm}$.

Table 4: Statistical treatment between the conductivity values of lactose and latex, and lactose and juice in plants gathered in May 2008, considering "p value" with $95 \%$ confidence interval.

\begin{tabular}{|c|c|c|}
\hline Dilutions & $\begin{array}{c}\text { Lactose vs Latex } \\
\text { (p-value) }\end{array}$ & $\begin{array}{c}\text { Lactose vs Juice } \\
\text { (p-value) }\end{array}$ \\
\hline $\mathbf{3} \mathbf{l m}$ & 0.874 & 0.541 \\
\hline $\mathbf{4} \mathbf{l m}$ & 0.458 & 0.325 \\
\hline $\mathbf{5} \mathbf{l m}$ & $0.003^{*}$ & $0.018^{*}$ \\
\hline $\mathbf{6} \mathbf{l m}$ & 0.198 & 0.756 \\
\hline $\mathbf{7} \mathbf{l m}$ & $0.028^{*}$ & $0.041^{*}$ \\
\hline $\mathbf{8} \mathbf{l m}$ & 0.483 & $0.016^{*}$ \\
\hline $\mathbf{9} \mathbf{l m}$ & $0.017^{*}$ & 0.057 \\
\hline $\mathbf{1 0} \mathbf{l m}$ & 0.526 & 0.732 \\
\hline
\end{tabular}

*Statistically significant difference

The results obtained with the latex from the plants gathered in May 2008 showed a different pattern. In this analysis, HDs $5 \mathrm{~lm}$ and $9 \mathrm{~lm}$ showed statistically significant difference (Figure 3, Table 3), indicating that the moment of gathering influenced the phytochemical composition of E. tirucalli, and also possibly the properties of its HDs.

\section{Cytotoxicity assay}

Results obtained by MTT assay showed significant difference $(\mathrm{p}<0.05)$ in cell viability when MCF7 cells were treated with 5\% (Figure 3-A) and 10\% (Figure 3-B) E. tirucalli $5 \mathrm{~lm}$ prepared from the latex and juice of plants gathered in May 2008. There was statistical difference among the groups that received HDs of $E$. tirucalli (juice and latex $5 \mathrm{~lm}$ ), lactose $5 \mathrm{~lm}$ and distilled water by comparison to the control group (cells without treatment).

The results obtained by MTT assay after incubation with $5 \%$ HDs of E. tirucalli (Figure 3A) showed increase in MCF-7 viability by comparison to the respective controls (DW and LDLM). However, when the cells were incubated with $10 \%$ HDs of E. tirucalli and controls there was significant increase $(\mathrm{p}<0.018)$ in cell viability induced only by the latex (Figure 4B), probably due to variations in the osmolarity of the culture medium. 


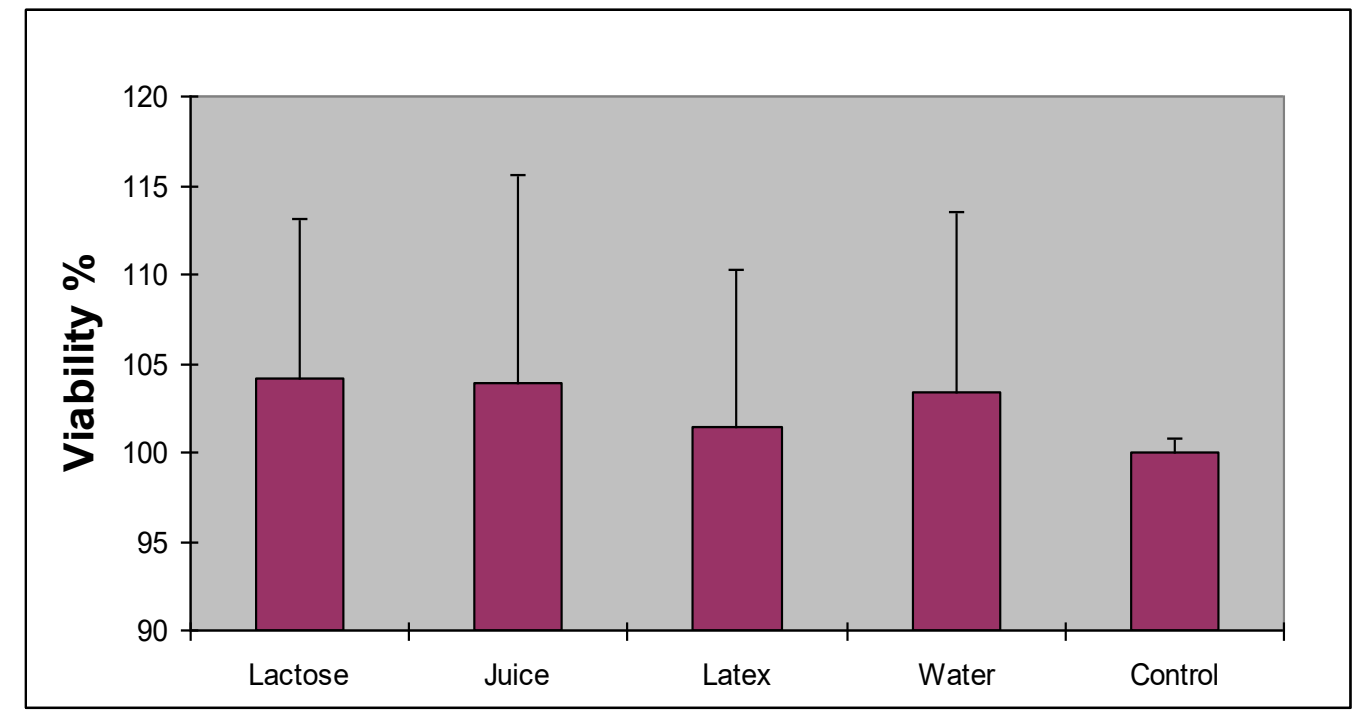

Figure $3 \mathrm{~A}$

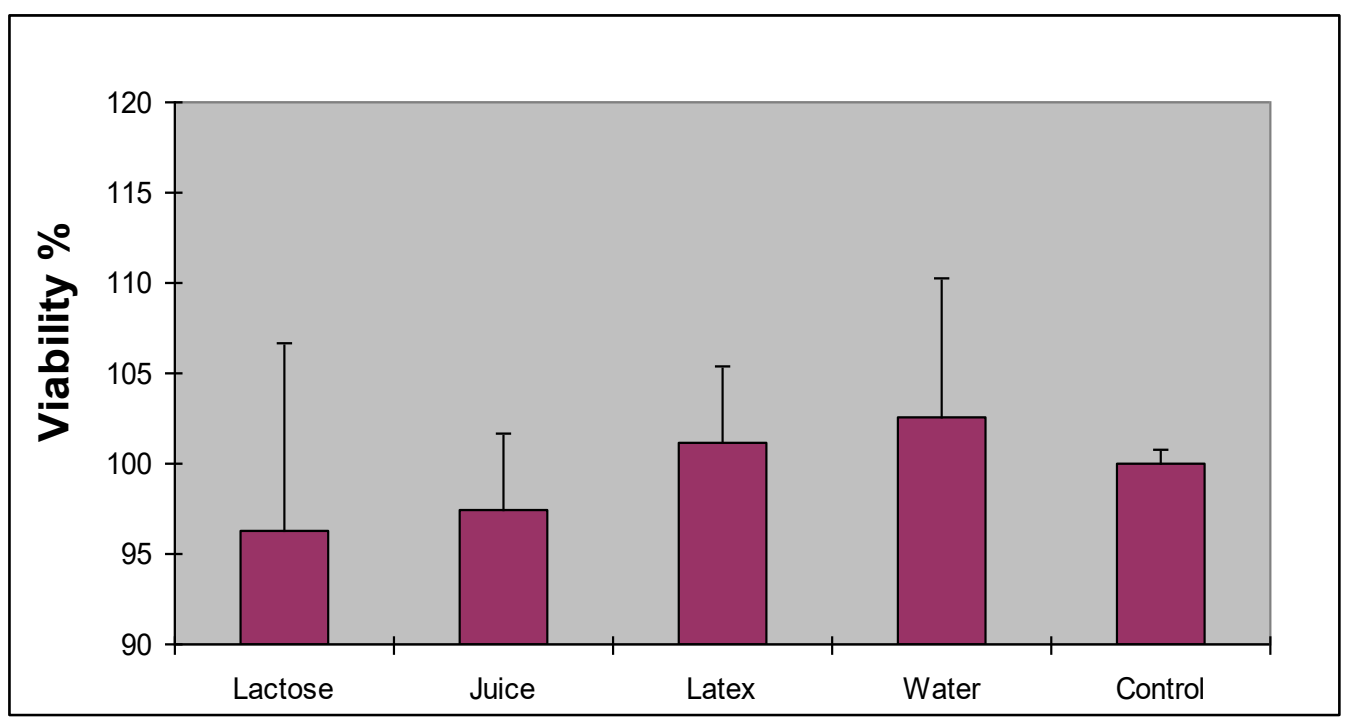

Figure 3B

Figures 3 (A and B): Viability of MCF7 cells incubated for 24 hours with $5 \%$ and $10 \%$ E. tirucalli 5 $\operatorname{lm}$ (juice and latex) and respective controls (distilled water - DW, lactose $5 \mathrm{~lm}$-LDLM, control), prepared from plants gathered in May 2008. A: MCF7 citotoxicity induced by $5 \%$ E. tirucalli $5 \mathrm{~lm}$; B: MCF7 citotoxicity induced by $10 \% \mathrm{E}$. tirucalli $5 \mathrm{~lm}$. Values are means $\pm \mathrm{SD}$ of 3 independent experiments performed in quintuplicate $(n=15)$.

Table 5 describes the statistical results considering "p value" with $95 \%$ confidence interval for $5 \%$ and $10 \% E$. tirucalli $5 \mathrm{~lm}$ gathered in May 2008.

T-test showed statistically significant differences between *lactose $5 \mathrm{~lm}$ vs control cells, * $\mathrm{latex} 5 \mathrm{~lm}$ vs control cells (5\% and 10\%), *juice $5 \mathrm{~lm}$ vs control cells, * ${ }^{*}$ ater vs control cells, *lactose $5 \mathrm{~lm}$ vs water, * $\mathrm{latex} 5 \mathrm{~lm}$ vs water, juice $5 \mathrm{~lm}$ vs water. 
Table 5: Statistical analysis of HDs from latex and juice of E. tirucalli gathered in May 2008, considering " $p$ value" with 95\% confidence interval, extracted from MTT graphs.

\begin{tabular}{|c|c|c|}
\hline Samples & $\begin{array}{c}\text { Concentration 5\% } \\
\text { (p-value) }\end{array}$ & $\begin{array}{c}\text { Concentration 10\% } \\
\text { (p-value) }\end{array}$ \\
\hline Lactose 5 lm vs Control & $<0.001^{*}$ & 0.279 \\
\hline Latex 5 lm vs x Control & $<0.001^{*}$ & $0.018^{*}$ \\
\hline Juice 5 lm vs Control & $0.002^{*}$ & 0.231 \\
\hline Water vs Control & $<0.001^{*}$ & 0.225 \\
\hline Latex 5 lm vs Lactose 5 lm & 0.910 & 0.769 \\
\hline Juice 5 lm vs Lactose 5 lm & 0.463 & 0.593 \\
\hline Lactose 5 lm vs Water & $0.006^{*}$ & 0.768 \\
\hline Latex 5 lm x Water & $0.006^{*}$ & 0.802 \\
\hline Juice 5 lm vs Water & $0.002^{*}$ & \\
\hline
\end{tabular}

*Statistically significant difference

Our results differ from those obtained by Aquino et al. in a previous work [21]. These authors showed a significant fall $(\mathrm{p}<0.05)$ in $\mathrm{MCF} 7$ viability between cells incubated with $E$. tirucalli $30 \mathrm{cH}$ and the corresponding HD of ethanol. Considering the presence of molecules of E. tirucalli, Aveloz $30 \mathrm{cH}$ and Aveloz 5 $\mathrm{lm}$ are both highly diluted, but for the presence of lactose remnants. Thus, we could not explain this different pattern evaluating only the tumoral metabolic aspect. Nevertheless, our results suggest that the effects observed might not be due to the solvent, but to the process of preparation, a hypothesis that must be verified in future works. Also, our findings might be attributed to a specific behavior of high-diluted systems whose dynamics are not completely clear yet.

\section{Conclusions}

The results obtained in this and in previous studies indicate that physical chemical parameters and biochemical features of MCF-7 cells are modified, even in the absence of molecules of E. tirucalli. Besides, the LM scale might have a different behaviour in the conductivity measurements and cytotoxicity features when compared with the centesimal scale. Further studies are under way to correlate the physical chemical properties of highly diluted solutions of other homeopathic medicines to improve the understanding about dynamized systems.

\section{References}

[1] Elia V, Baiano AS, Duro I, Napoli E, Nicolli M, Nonatelli L. Permanent physic-chemical properties of extremely diluted solutions of homeopathic medicines. Homeopathy. 2004;93:144-150. 
[2] Elia V, Elia L, MontaninoM, Napoli E, Niccoli M, Nonatelli L. Conductometric studies of the serially diluted and agitated solutions on an anomalous effect that depends on the dilution process. J Mol Liq. 2007; 135:158-165.

[3] Elia V, Napoli E, Germano R. The "Memory of Water": an almost deciphered enigma. Dissipative structures in extremely dilute aqueous solutions. Homeopathy. 2007; 96(3):163-169.

[4] Rey L. Can low-temperature thermoluminescence cast light on the nature of ultra-high dilutions? Homeopathy. 2007; 96(3):170-174.

[5] Chaplin MF. The memory of water: an overview. Homeopathy. 2007; 96(3):143-150.

[6] Milgrom LR. Conspicuous by its absence: the memory of water, macro-entanglement, and the possibility of homeopathy. Homeopathy. 2007; 96(3):209-219.

[7] Rao ML, Roy R, Bell IR, Hoover R. The defining role of structure (including eptiaxy) in the plausibility of homeopathy. Homeopathy. 2007; 96(3):175-182.

[8] Elia V, Elia L, Cacace P, Napoli E, Noccoli M, Savarese F. The extremely diluted solutions as multivariable systems: a study of calorimetric and conductometric behaviour as a function of the parameter time. J. Therm Anal Cal 2006; 84(2):317-323.

[9] Elia V, Marchese M, Montanino M, Napoli E, Niccoli M, Nonatelli L, Ramaglia A, Hydrohysteretic phenomena of extremely diluted solutions induced by mechanical treatments: a calorimetric and conductometric study at $25^{\circ} \mathrm{C}$. J Sol Chem. 2005; 34(8):947-960.

[10] Holandino C, Harduim RC, Veiga VF, Garcia S, Zacharias CR. Modeling Physical-Chemical Properties of High Dilutions: an electrical conductivity study. Int J High Dil Res. 2008;7:165-173.

[11] Holandino C, Leal FD, Barcellos B, Campos MA, Oliveira R, Veiga VF, Garcia S, Zacharias, CR. Mechanical versus handmade succussions: a physical chemistry comparison. Signal and Images II: GIRI's book. Bonamin LV, editor. London (UK): Springer; 2008.

[12] Davenas E, Beauvais F, Amara J, Oberbaum M, Robinzon B, Miadonna A, Tedeschi A, Pomeranz B, Fortner P, Belon P, Sainte-Laudy J, Poitevin B, Benveniste J. Human basophil degranulation triggered by very dilute antiserum against IgE. Nature 1988; 333 (6176): 816-818.

[13] Adler UC, Amarilys TC, Adler MS, Padula AE, Garozzo EN, Galhardi WMP Da padronização farmacêutica à pesquisa clínica: 20 anos de experiência com diluições cinquenta-milesimais. Revista de Homeopatia. 2010;73(1/2):57-67.

[14] Hahnemann S. Organon of Medicine 6th edn. London: Orion Books Ltd; 2003.

[15] Imai S, Sugira M, Mizuno F, Ohigashi H, Koshimizu K, Chiba S, Osato T. African Burkitt's Lymphoma: A plant, Euphorbia tirucalli, reduces Epstein-Barr Virus-Specific Cellular Immunity. Anticancer Research 1994;14(3A): 933 - 936. 
[16] Furstenberg G \& Hecker E. On the active principles of the Euphorbiaceae, XII. Highly unsaturated irritant diterpene esters from Euphorbia tirucalli originating from Madagascar. Journal of Natural Products, 1986; 49(3): 386 - 397.

[17] Furstenberger G, Hecker E. On the active principles of the Euphorbiaceae, XII. Highly unsaturated irritant diterpene esters from Euphorbia tirucalli originating from Madagascar. J Nat Prod 1986; 49: 386397.

[18] Sugiura M, Imai S, Sakurada K, Myiazaki T, Osato T. Cryptic dysfunction of cellular immunity in asymptomatic human immunodeficiency virus (HIV) carriers and its actualization by an environmental immunosuppressive factor. In Vivo 1994; 8: 1019-1022.

[19] Betancur-Galvis LA, Morales GE, Forero JE, Roldan J. Cytotoxic and antiviral activities of colombian medicinal plant extracts of the Euphorbia genus. Mem Inst Osw Cruz 2002; 97(4):541-546.

[20] Bosch CA. Is endemic Burkitt's lymphoma an alliance between three infections and a tumour promoter? The Lanc Oncol. 2004;5:738-746.

[21] Aquino CL, Barbosa GM, Barbosa GM, Varricchio MCBN, Veiga VF, Kurster R, Zancan P, Penna MS, Holandino, C. High dilutions of Euphorbia tirucalli L. (AVELOZ) modify the viability and glycolitic metabolism of cell lines. Int J High Dil Res. 2008; 7:132-139.

[22] Varricchio MCBN, Pereira C, Gomes T, Daut E, Sales FC, Aquino CL, Barbosa GM, Gomes NBN, Pyrrho AS, Hobaica PEM, Branco MTLC, Kurster R, Holandino C. Chronic toxicological effects of high diluted solutions of Aveloz (Euphorbia tirucalli L.) on healthy mice: a preliminary study. Int J High Dil Res. 2008; 7:174-178, 2008.

[23] Brazil. Brazilian Homeopathic Pharmacopeia. 2a ed. São Paulo: Atheneu; 1997.

[24] Mosmann T. Rapid colorimetric assay for cellular growth and survival: application to proliferation and cytotoxic assays. J Immunol Met 1983; 65:55-63.

[25] Varricchio MCBN. Estudos integrados: biotecnologia, toxicologia, metabólitos especiais e atividade antitumoral de Euphorbia tirucalli L [Integrative Studies: biotechnology, toxicology, special metabolites and antitumoral activity of Euphorbia itrucalli L]. [dissertation] Maio 2005, PBV, UFRJ. Portuguese.

[26] Barbosa GM, Veiga VF, Zancan P, Penna MS, Holandino, C. Estudo da sazonalidade climática sobre a atividade citotóxica de soluções ultradiluídas e dinamizadas de Euphorbia tirucalli Lineu (aveloz) [Study of the climatic seasonality on cytotoxic activity of ultra diluted solutions and dynamized of Euphorbia tirucalli Lineu (aveloz)] In: XXIV Congresso Brasileiro de Homeopatia; 2008, São Paulo. Portuguese.

\section{Avaliação físico-química e citotóxica de soluções altamente diluídas de euphorbia tirucalli $l$. Preparada pelo método cinqüenta milesimal (lm).}




\section{RESUMO}

Motivação: Embora Hahnemann tenha descrito o método LM na 6 a . Edição do Organon da Arte de Curar, poucas pesquisas tem sido feitas sobre as propriedades físico-químicas destas preparações. Além disso, ainda não existem evidências que apontem para a correlação entre propriedades físico-químicas e os efeitos biológicos das altas diluições. Objetivos: determinar características físico-químicas das preparações LM tais como condutividade elétrica, $\mathrm{pH}$ e índice de refração, bem como o efeito biológico em modelos experimentais. Materiais e Métodos: foi analisada uma série de diluições desde $1 \mathrm{~lm}$ até $10 \mathrm{~lm}$ de Euphorbia tirucalli L., preparada a partir do látex e do suco da planta. Para considerar as características sazonais desta planta, usamos 2 populações diferentes, colhidas uma em Junho de 2007 e outra em Maio de 2008. Além disso, o efeito citotóxico da Euphorbia tirucalli L. $5 \mathrm{~lm}$ foi testado em células humanas cancerosas (MCF7) através de ensaio MTT. Conclusões: Algumas diferenças entre as duas populações foram observadas. No entanto, nenhuma correlação clara pode ser observada entre as propriedades físico-químicas e a atividade biológica.

Palavras-chave: altas diluições, método LM, condutividade elétrica, $\mathrm{pH}$, índice de refração, citotoxicidade, Euphorbia tirucalli L.

\section{Evaluación físico-química y citotóxica de soluciones altamente diluídas de Euphorbia tirucalli L. preparadas por el método homeopático cincuenta milesimal (LM).}

\section{RESUMEN}

Motivación: Aunque Hahnemann describió el métodocincuenta milesimal (LM) en la 6 a edición del Organon del Arte Médica, muy poca investigación se ha realizado sobre las propiedades físico-químicas de estos preparados homeopáticos. Por otra parte, todavía no hay pruebas que permitan la correlación entre las presuntas propiedades físico-químicas y los efectos biológicos, de las altas diluciones. Objetivos: evaluar las características físico-químicas de los preparados LM, incluyendo conductividad eléctrica, $\mathrm{pH}$ y el índice de refracción, y su efecto en modelos biológicos experimentales. Materiales y métodos: las muestras para el análisis físico-químico fueron diluciones 1 a $10 \mathrm{~lm}$ de Euphorbia tirucalli L. preparadas a partir del látex y el jugo de la planta. Para descartar las características sazonales de esta planta, dos poblaciones diferentes fueron utilizadas, una recogida en junio de 2007 y otro en mayo de 2008. Además, el efecto citotóxico de Euphorbia tirucalli $5 \mathrm{~lm}$ fue probado en células humanas de cáncer de mama (MCF7) a través del ensayo MTT. Conclusiones: Algunas diferencias entre las dos colecciones se observaron. Sin embargo, ninguna correlación clara se observó entre las propiedades físicas- químicas y actividad biológica.

Palabras claves: altas diluciones, método LM, conductividad eléctrica, $\mathrm{pH}$, índice de refracción, citotoxicidad, Euphorbia tirucalli

\section{(c)) EY-NC-ND Licensed to GIRI}

Support: authors declare that this study received no funding

Conflict of interest: authors declare there is no conflict of interest

Received: 17 April 2010; Revised: 20 June 2010; Published: 30 June 2010.

Correspondence author: Carla Holandino, cholandino@yahoo.com; Sheila Garcia, sheiloka@globo.com

How to cite this article: Garcia S, Harduim RC, Homsani F, Zacharias CR, Kuster RM, Holandino C.Physical chemical and citotoxic evaluation of highly diluted solutions of Euphorbia tirucalli L. prepared through the fifty milesimal homeopathic method. Int J High Dilution Res [online]. 2010 [cited YYYY Month dd]; 9(31):63-73. Available from: http://www.feg.unesp.br/ ojs/index.php/ijhdr/article/view/383/439 . 